\title{
Index properties of alkalis treated expansive and non expansive soil contaminated with acids
}

\author{
H.N.Ramesh ${ }^{1}$ and S.D. Venkataraja Mohan ${ }^{2}$, \\ ${ }^{1,2}$ (Department of Civil Engineering, University Visvesvaraya College of Engineering, J.B.Campus, Bangalore \\ University, Department of Civil Engineering, Dr.Ambedkar Institute of Technology, Bangalore-560056, India)
}

\begin{abstract}
In recent years attention has been given to the acidification and alkalization of the soils to understand physico-chemical and Engineering properties. The effect of Sulphuric acid and Orthophosphoric acid with Calcium Carbonate and Magnesium Carbonate treated soils is studied. The Optimum percentages of $\mathrm{CaCO}_{3}$ and $\mathrm{MgCO}_{3}$ mix were found for Black Cotton soil and Red Earth based on compaction test. Liquid limit is decreased with $\mathrm{CaCO}_{3}$. and increased with $\mathrm{MgCO}_{3}$. Plastic limit is increased with $\mathrm{CaCO}_{3}$ and decreased with. $\mathrm{MgCO}_{3}$. Shrinkage limit is increased with $\mathrm{CaCO}_{3}$ and decreased with $\mathrm{MgCO}_{3}$. Acidification of alkalis treated soils by one normal Sulphuric acid and one normal Ortho Phosphoric acid showed alteration and impairment in index properties. However, the effect of $1 \mathrm{~N}_{3} \mathrm{PO}_{4}$ on the alkali treated soils has less negative effect than with $1 \mathrm{~N}_{2} \mathrm{SO}_{4}$ on the index properties. It is evident that the index properties of soils are altered when compared with their initial characteristics. The reasons for the observed behavior of soils are addressed.
\end{abstract}

Keywords: Index properties, Sub surface Contamination, diffused double layer, particle aggregation, cation exchange,

\section{Introduction}

Modern construction requires not only profound preliminary study of the foundation material, but also a thorough knowledge of the factors causing its changes in the life time of the structures supported by it. Behavior of any chemical or contaminant in the soil depends upon its properties and its interactivity with soil. The major sources of subsurface and surface contamination are land disposal of industrial, mining, agricultural wastes and accidental spillage of chemicals. Results of some studies indicate that the detrimental effect of seepage of acids and bases into subsoil can cause severe foundation failures. Sridharan et. al [1981]1 reports that extensive cracking damage to the floors, pavements and foundations of light industrial building in a fertilizer plant in Kerala State. Joshi et al [1994]2 reports the severe damage occurred to the interconnecting piping of a phosphoric acid storage tank in particular and also to the adjacent buildings due to differential movements between pump and acid tank foundations of a fertilizer plant in Calgory, Canada. Kumapley and Ishola [1985]3 reported a similar case of accidental spillage of highly concentrated caustic soda solution as a result of spillage from cracked drains in an industrial establishment in Tema, Ghana which caused considerable structural damage to a light industrial building in the factory, in addition to localized subsidence of the area. Anand J Puppal et.al [2006]4 has reported sulfate-induced heave was caused by the formation and hydration of Ettringite mineral in lime treated sulfate-rich natural soils.

Expansive soils are found in arid and semiarid regions of the world where the annual evaporation exceeds precipitation. Hot climate and poor drainage conditions are usually associated with the formation of these soils. The colour of these soils varies from deep black to grey and sometimes even reddish to yellowish. In India, these soils are generally called black cotton soil and covers $25 \%$ of total land mass.

They experience large volume changes upon exposure to climatic change and chemical contamination; they shrink upon drying accompanied by cracking and swell when water comes in contact exerting enormous pressures on the structure. Since constructions on black cotton soils cannot be avoided their properties are altered by many ways like mechanical, thermal, chemical and other means to make acceptable or rejected on contamination. The index and engineering properties of the ground gets modified in the vicinity of the industrial pants mainly as a result of contamination by the industrial wastes disposed. The major sources are the disposal of industrial water and accidental spillage of chemicals during the course of industrial operations. The leakage of industrial effluent in to subsoil directly affects the use and stability of the supported structure.

Red earth covers large area in Indian subcontinent and it is a natural soil available in vast areas of India and also in Karnataka. These soils are mostly found in semi arid regions. Isbell, [1996]5, opines that the soil is a typical non-expansive clayey soil containing kaolinite as its chief mineral constituent and acidification and alkalization of this soil alters the index and Engineering properties of soil. Sivapullaiah and Manju, [2005]6 have investigated kaolinite-alkali interaction and effects on basic properties of Red Earth and reports that soil contaminated with different concentration of alkali shows an increase in liquid limit as compared to water. 


\subsection{Materials}

\section{MATERIALS AND METHODS}

\subsubsection{Black Cotton soil}

The Black Cotton soil is obtained from Davanagere district of Karnataka state in India. This is residual soil and is collected at a depth of one meter below the natural ground surface. The soil was dried and passed through IS sieve 425 microns before being used for investigation. It is classified as "CH" group as per IS classification (1970). The physical and chemical properties of Black Cotton soil have been listed in table I and II respectively.The soil is a typically non-expansive clayey soil containing Kaolinite as its chief mineral constituent and was collected at a depth of 1.5 meters below the natural ground surface at the Bangalore University, Jnanabharathi campus, Bangalore, India. To ensure the uniformity of the soil sample it was oven dried, pulverized and sieved through 425 micron BIS sieve before used in the present investigation.

\subsubsection{Red Earth}

The soil is a typically non-expansive clayey soil containing Kaolinite as its chief mineral constituent and was collected at a depth of 1.5 meters below the natural ground surface at the Bangalore University, Jnanabharathi campus, Bangalore, India. To ensure the uniformity of the soil sample it was oven dried, pulverized and sieved through 425 micron BIS sieve before used in the present investigation.

\subsubsection{Alkalis}

Chemicals used in the study are Calcium Carbonate $\left(\mathrm{CaCO}_{3}\right)$, Magnesium Carbonate $\left(\mathrm{MgCO}_{3}\right)$. These chemicals have been obtained from Qualigens Fine Chemicals and Sd Fine Chemicals Pvt. Limited, Mumbai India. Properties of $\mathrm{CaCO}_{3}$ and $\mathrm{MgCO}_{3}$ are listed in table III. The Calcium Carbonate and Magnesium Carbonate are in white powder form and insoluble in water but reacts with constituents of any soil.

\subsubsection{Acids}

The acids used in the study are Sulphuric acid $\left(\mathrm{H}_{2} \mathrm{SO}_{4}\right)$ and Orthophosporic acid $\left(\mathrm{H}_{3} \mathrm{PO}_{4}\right)$. The strength of the acids was reduced to one normal solution.

Table 1. Physical properties of Block Cotton Soil.

\begin{tabular}{|c|c|}
\hline Color & Black \\
\hline Specific gravity & 2.64 \\
\hline Grain size analysis & $9 \%$ \\
\hline Fine sand & $31 \%$ \\
\hline Silt & $60 \%$ \\
\hline Clay & \\
\hline Atterberg's limits & $77 \%$ \\
\hline Liquid limit & $30.75 \%$ \\
\hline Plastic limit & $49.85 \%$ \\
\hline Plasticity Index & $8.3 \%$ \\
\hline Shrinkage Limit & $33.7 \%$ \\
\hline Optimum moisture Content & $13.8 \mathrm{kPa}$ \\
\hline Maximum dry density & \\
\hline
\end{tabular}

Table II: Chemical Analysis of Black Cotton soil

\begin{tabular}{|c|c|}
\hline Chemical composition & Percentage \\
\hline Silica $\left(\mathrm{SiO}_{2}\right)$ & 52.85 \\
\hline Alumina $\left(\mathrm{Al}_{2} \mathrm{O}_{3}\right)$ & 12.24 \\
\hline Ferric Oxide $\left(\mathrm{Fe}_{2} \mathrm{O}_{3}\right)$ & 8.04 \\
\hline Calcium Oxide $(\mathrm{CaO})$ & 6.01 \\
\hline Magnesium Oxide $(\mathrm{Mgo})$ & 2.94 \\
\hline Titanium Dioxide $\left(\mathrm{TiO}_{2}\right)$ & 0.24 \\
\hline Potassium Oxide $\left(\mathrm{K}_{2} \mathrm{O}\right)$ & 0.48 \\
\hline Sodium Oxide $\left(\mathrm{N}_{2} \mathrm{O}\right)$ & 0.26 \\
\hline Loss of ignition & 16.18 \\
\hline
\end{tabular}

Table III:Physical properties of Red Earth

\begin{tabular}{|c|c|}
\hline Colour & Brick red \\
\hline Specific Gravity & 2.59 \\
\hline Liquid limit (\%) & 39.3 \\
\hline Plastic limit (\%) & 26.1 \\
\hline Plasticity Index (\%) & 13.2 \\
\hline Shrinkage limit (\%) & 15.4 \\
\hline Fine sand fraction (\%) & 11.0 \\
\hline Silt fraction (\%) & 42.0 \\
\hline Clay fraction (\%) & 47.0 \\
\hline Maximum dry density (kN/m $\left.{ }^{3}\right)$ & 16.3 \\
\hline Optimum moisture content (\%) & 20.26 \\
\hline
\end{tabular}


Table IV. Chemical properties of Red Earth.

\begin{tabular}{|c|c|}
\hline Chemical composition & Percentage \\
\hline Silicon dioxide & 60.4 \\
\hline Alumina & 15.05 \\
\hline Iron oxide & 6.6 \\
\hline Titanium dioxide & 0.2 \\
\hline Calcium oxide & 6.9 \\
\hline Magnesium oxide & 1.7 \\
\hline Potassium oxide & 0.4 \\
\hline Loss on ignition & 8.4 \\
\hline Sodium oxide & 0.3 \\
\hline
\end{tabular}

Table V.. Properties of Chemicals used.

\begin{tabular}{|c|c|c|}
\hline Properties & $\mathrm{CaCO}_{3}$ & $\mathrm{MgCO}_{3}$ \\
\hline $\begin{array}{l}\text { Molecular } \\
\text { Weight }\end{array}$ & 100.1 & 84.3 \\
\hline Color & White & White \\
\hline $\begin{array}{l}\text { Crystal } \\
\text { Symmetry }\end{array}$ & Rhombic & Trigonal \\
\hline $\begin{array}{l}\text { Refractive } \\
\text { Index } n_{D}\end{array}$ & 1.681 & 1.51 \\
\hline Density & $2.71 \mathrm{~g} / \mathrm{cc}$ & $2 \mathrm{~T} .05 \mathrm{~g} / \mathrm{cc}$ \\
\hline $\begin{array}{l}\text { Melting } \\
\text { Point } \\
\end{array}$ & $825^{\circ} \mathrm{C}$ & $990^{\circ} \mathrm{C}$ \\
\hline $\begin{array}{l}\text { Solubility } \\
\text { in } 100 \\
\text { parts } \\
\text { solvent }\end{array}$ & $\begin{array}{c}0.013 \mathrm{~g} / 100 \mathrm{ml} @ \\
20^{\circ} \mathrm{C} \text {,soluble in } \\
\text { acids }\end{array}$ & $\begin{array}{c}0.01 \mathrm{~g} / 100 \mathrm{ml} @ \\
20^{\circ} \mathrm{C} \text {,soluble } \\
\text { in acids }\end{array}$ \\
\hline Assay & $8.5 \%$ & $95 \%$ \\
\hline
\end{tabular}

\subsection{Methods}

Index properties were determined as per IS-2720 part 5-6.Various percentages of $\mathrm{CaCO}_{3}$ and $\mathrm{MgCO}_{3}$ additives are mixed to soils individually and acidification is done with one normal Sulphuric acid $\left(\mathrm{H}_{2} \mathrm{SO}_{4}\right)$ and Orthophosphoric acid $\left(\mathrm{H}_{3} \mathrm{PO}_{4}\right)$ for the optimum combination of soils and Carbonates individually. Importance has been accorded to qualitative magnitude of impact of contamination and mechanism due to which this happens in this presentation.

\section{RESULTS AND DISCUSSIONS}

\subsection{Effect of Calcium Carbonate and Magnesium Carbonate on Liquid limit of Black Cotton Soil}

When Black cotton soil is treated with different percentage of Calcium Carbonate liquid limit decreased from $77 \%$ to $64 \%$. This is due to the reduction in thickness of diffused double layer of clay particles by exchange of the monovalent cat ions by divalent calcium ions. However with curing the liquid limit for Black cotton soil increases for 7 days curing due to flocculation of clay particle and decreased slightly for 30 days curing. Optimum percentage of $\mathrm{CaCO}_{3}$ is found to be $15 \%$ as shown in Fig.1

Magnesium Carbonate $\left(\mathrm{MgCO}_{3}\right)$ increased the liquid limit of Black cotton soil from $77 \%$ to $87 \%$ as shown in Fig. 2 due to cation exchange property of Magnesium ions. But with curing, the liquid limit for Black cotton soil also increased to $\max 89 \%$ as shown in Fig.2due to increased cation exchange. Further increase in percentage $\mathrm{MgCO}_{3}$, the liquid limit is decreased marginally for 30 days curing due to increase in double layer.

\subsubsection{Effect of Calcium Carbonate and Magnesium Carbonate on Liquid limit of Red Earth}

When Red Earth is treated with different percentage of Calcium Carbonate liquid limit decreased from 45.5 percent to 39 percent. This is due to the reduction in thickness of diffused double layer of clay particles by exchange of the monovalent cat ions by divalent calcium ions. However with curing the liquid limit for Red Earth increases slightly for 7 days due to flocculation of clay particle and increased upto 41.5 percent for 30 days curing. Optimum decrease in liquid limit is found to be 37.5 percent at 15 percent $\mathrm{CaCO}_{3}$ as shown in Fig.3.Magnesium Carbonate $\left(\mathrm{MgCO}_{3}\right)$ increased the liquid limit of Red Earth from 45.5 percent to 50.7 at 10 
percent $\mathrm{MgCO}_{3}$ and upto 54.5 percent as shown in fig.4 due to cation exchange property of Magnesium ions. But with curing, the liquid limit for Red Earth is decreases marginal for 7days and marginally increased to 52 percent at 20 percent $\mathrm{MgCO}_{3}$ for 30 days curing due to increased cation exchange and increase in double layer.

\subsubsection{Effect of Calcium Carbonate and Magnesium Carbonate on Plastic limit of Black Cotton Soil}

With the addition of various percentages $\mathrm{CaCO} 3$ to Black cotton soil the plastic limit is increased from $21.6 \%$ to $32.1 \%$ for immediate mixing. For 7 days and 30 days curing plastic limit of $\mathrm{CaCO}_{3}$ treated Black cotton soil is found to have been increased marginally from $31.6 \%$ to $39.1 \%$ as shown in Fig.5. This is due to flocculation of clay particle which hold the water during the curing period. Various percentages of $\mathrm{MgCO}_{3}$ addition resulted in an increase in plastic limit values from $21.6 \%$ to $34.25 \%$ at $5 \%$ (optimum) addition and thereafter Plastic limit decreased marginally to 28.5\%.Curing of MgCO3 treated Black cotton soil to7 and 30 days respectively shown decrease in Plastic limit upto $24.45 \%$ as shown in Fig.6. The decrease in plastic limit may be due to the depression of diffused double layer thickness and consequent aggregation particles.

\subsubsection{Effect of Calcium Carbonate and Magnesium Carbonate on Plastic limit of Red Earth}

With the addition of various percentages $\mathrm{CaCO}_{3}$ to Red Earth the plastic limit is decreased from 26.2 percent to 20.9 percent for immediate mixing. For 7 days and 30 days curing plastic limit of $\mathrm{CaCO}_{3}$ treated Red Earth is found to have been increased marginally from 26.2 percent upto 28.3 percent as shown in Fig.7. This is due to flocculation of clay particle which hold the water during the curing period.

Various percentages of $\mathrm{MgCO}_{3}$ addition resulted in an increase in plastic limit values from 26.2 percent to 28.8 percent at optimum percentage addition for immediate mixing. Curing of $\mathrm{MgCO}_{3}$ treated Red Earth to 7 and 30 days respectively shown increase in Plastic limit upto 30.3 percent at 20 percent $\mathrm{MgCO}_{3}$ as shown in Fig.8.

\subsubsection{Effect of Calcium Carbonate and Magnesium Carbonate on Shrinkage limit of Black Cotton Soil and Red Earth}

Shrinkage limit is increased from $8.6 \%$ to $11.1 \%$ for various percentages of $\mathrm{CaCO}_{3}$ treated Black cotton soil. Upon curing to 7 and 30 days respectively, the Shrinkage limit is increased to a maximum of $12.33 \%$ for $20 \%$ addition of $\mathrm{CaCO}_{3}$ as shown in Fig.9. Addition of 5\% MgCO3(opt) to BC soil increases the Shrinkage limit to $9.6 \%$ and further addition of $\mathrm{MgCO}_{3}$ decreases the Shrinkage limit to $7.8 \%$. However the Shrinkage limit further increases for 7 and 30 days curing respectively as shown in Fig.10. Shrinkage limit is increased from 13.55 percent to 20.13 percent for Red Earth treated with optimum percentages of $\mathrm{CaCO}_{3}$. With curing, the Shrinkage limit is decreased to 17.25 percent for 7 days and further decreased to 15.5 for 30 days as shown in Fig. 11.

\subsubsection{Effect of 1N Sulphuric Acid on Liquid limit of Black Cotton Soil and Red earth}

With the acidification to optimum percentage of $\mathrm{CaCO} 3$ treated Black cotton soil by $1 \mathrm{~N}$ Sulphuric acid the liquid limit is slightly increased and in case of Magnesium Carbonate treated Black cotton soil the liquid limit is decreased marginally from those liquid limit values of the Magnesium carbonate treated soil. In both $\mathrm{CaCO}_{3}$ and $\mathrm{MgCO}_{3}$ treated Black cotton soil, $1 \mathrm{~N}$ Sulphuric acid increased the liquid limit to minimum extent for 7 days curing and decreased the liquid limit marginally on 30 days of curing as shown in Fig.1.Red Earth treated with optimum percentage of $\mathrm{CaCO}_{3}$ increases liquid limit marginally with addition of $1 \mathrm{~N}$ Sulphuric acid. $1 \mathrm{~N}$ Sulphuric acid increased the liquid limit to maximum 43.5 percent and for $\mathrm{MgCO}_{3}$ treated Red Earth liquid limit decreased to 49.2 percent for 30 days curing respectively as shown in Fig. 2

\subsubsection{Effect of 1N Ortho phosphoric Acid on Liquid limit of Black Cotton Soil and Red earth}

$1 \mathrm{~N}$ Orthophosporic acid increased the liquid limit from $64 \%$ to $66 \%$ for $\mathrm{CaCO}_{3}$ treated Black cotton soil and decreased the liquid limit from $87 \%$ to $75 \%$ for $\mathrm{MgCO}_{3}$ treated Black cotton soil respectively. With the curing of acid contaminated soil to 7 days the liquid limit is marginally increased and then it is decreased for 30 days of curing as shown in Fig. 1and 2.1Normal Orthophosporic acid increased the liquid limit from 38.9 percent to 46.5 percent for Red Earth treated with $\mathrm{CaCO}_{3}$ and also marginally decreased the liquid limit from 50.7 percent to 49.5 percent for $\mathrm{MgCO}_{3}$ treated Red Earth for immediate mixing. However, acidification of both optimum percent of $\mathrm{CaCO}_{3}$ and $\mathrm{MgCO}_{3}$ treated Red Earth showed marginal increase in liquid limit when cured for 7 and 30 days as shown in Figs. 3 and 4.

\subsubsection{Effect of 1N Sulphuric Acid on Plastic limit of Black Cotton Soil and Red earth}

Acidification with $1 \mathrm{~N} \mathrm{H}_{2} \mathrm{SO}_{4}$ to $15 \% \mathrm{CaCO}_{3}$ (optimum) treated Black cotton soil has shown slight decrease in plastic limit whereas for $5 \% \mathrm{MgCO}_{3}$ treated, it shown a fair decreasing value. For Black cotton soil alone $1 \mathrm{~N} \mathrm{H}_{2} \mathrm{SO}_{4}$ decreased the Plastic limit to $19.9 \%$. However for Curing of $\mathrm{CaCO}_{3}$ treated Black cotton soil to 
7 and 30 days a slight increase in plastic limit is noticed, but for $\mathrm{MgCO}_{3}$ treated $\mathrm{BC}$ soil, a slight decrease is noticed as shown in Figs.5 and 6. Red Earth treated with optimum percentage of $\mathrm{CaCO}_{3}$ decreases Plastic limit with addition of $1 \mathrm{~N}$ Sulphuric acid. However for Red Earth treated with optimum percentage of $\mathrm{MgCO}_{3}$ the Plastic limit decreases marginally However for Curing of $\mathrm{CaCO}_{3}$ and $\mathrm{MgCO}_{3}$ treated acidified Red Earth, to 7 and 30 days respectively, a decrease in plastic limit upto 14.2 percent is observed as shown in Figs. 5 and 6.

\subsubsection{Effect of 1N Ortho phosphoric Acid on Plastic limit of Black Cotton Soil and Red earth}

In both $\mathrm{CaCO}_{3}$ and $\mathrm{MgCO}_{3}$ treated $\mathrm{BC}$ soil the plastic limit is slightly decreased from $31.9 \%$ and $34.1 \%$ respectively on addition of $1 \mathrm{~N} \mathrm{H}_{3} \mathrm{PO}_{4}$. For 7 and 30 days cured samples a slight increase for $\mathrm{CaCO} 3$ treated and a slight decrease for $\mathrm{MgCO}_{3}$ treated soil is noticed. For BC alone it is decreased $24.2 \%$ and further decreased to negligible value on 7 and 30 days curing respectively as shown in Fig.5\&6. In both $\mathrm{CaCO}_{3}$ and $\mathrm{MgCO}_{3}$ treated Red Earth the plastic limit is slightly increased from 20.9 percent upto 23.5 percent and from 28.8 percent to 29.2 percent respectively on addition of $1 \mathrm{~N} \mathrm{H}_{3} \mathrm{PO}_{4}$. For 7 and 30 days cured samples a marginal increase in plastic limit is observed as shown in Fig. $7 \& 8$.

\subsubsection{Effect of $1 \mathrm{~N}$ Sulphuric Acid on Shrinkage limit of Black Cotton Soil and Red earth}

Addition of $1 \mathrm{~N} \mathrm{H}_{2} \mathrm{SO}_{4}$ to $15 \% \mathrm{CaCO}_{3}$ (opt) has reduced the Shrinkage limit to $8.9 \%$ and with Black cotton soil alone it is found increased slightly. Upon curing 7 and 30 days respectively, the shrinkage limit found increased to maximum $10.75 \%$. For $5 \% \mathrm{MgCO}_{3}$ treated $\mathrm{BC}$ soil $1 \mathrm{~N} \mathrm{H}_{2} \mathrm{SO}_{4}$ increased the shrinkage limit to $11.24 \%$. For curing to 7 and 30 days it is marginally increased. Addition of $1 \mathrm{~N}_{2} \mathrm{SO}_{4}$ to Red Earth alone increases the Shrinkage limit to $16.3 \%$, with curing the same to 7 and 30 days a marginal decrease in Shrinkage limit is found. An increase in Shrinkage limit to 23.1 percent for acidification of $\mathrm{CaCO}_{3}$ treated and slight decrease to 12.5 percent for acidification of $\mathrm{MgCO}_{3}$ treated Red Earth is observed as shown in Figs.9 \&10.

\subsection{Effect of 1N Ortho phosphoric Acid on Shrinkage limit of Black Cotton Soil and Red earth}

Addition of $1 \mathrm{~N} \mathrm{H}_{3} \mathrm{PO}_{4}$ to $\mathrm{BC}$ soil treated with $15 \% \mathrm{CaCO}_{3}$ the Shrinkage limit increases to $9.65 \%$. The Shrinkage limit increases further with increase in curing upto 7 and 30 days. However, with Black cotton soil treated with $5 \% \mathrm{MgCO}_{3}$ the Shrinkage Limit increases marginally with and without curing as shown in Figs. 10 and 11. Addition of $1 \mathrm{~N} \mathrm{H}_{3} \mathrm{PO}_{4}$ to Red Earth alone increases the Shrinkage limit,. However, for 7 and 30 days of curing the Shrinkage Limit increases marginally with optimum $\%$ of $\mathrm{CaCO}_{3}$ and with $\mathrm{MgCO}_{3}$ treated Red Earth. However curing effect showed decrease in Shrinkage limit for both alkalis treated Red Earth with $1 \mathrm{~N} \mathrm{H}_{3} \mathrm{PO}_{4}$ as shown in Figs. $11 \& 12$.

\section{FIGURES}

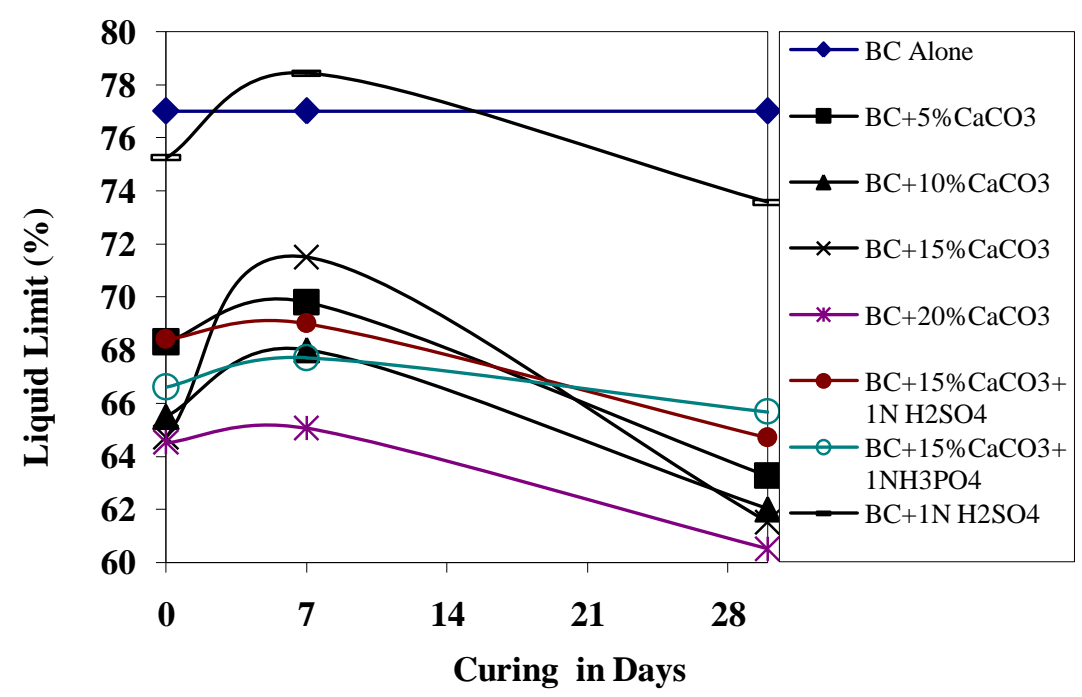

Fig 1. Variation of Liquid Limit of Black cotton soil with different percentage of additives at different curing periods. 


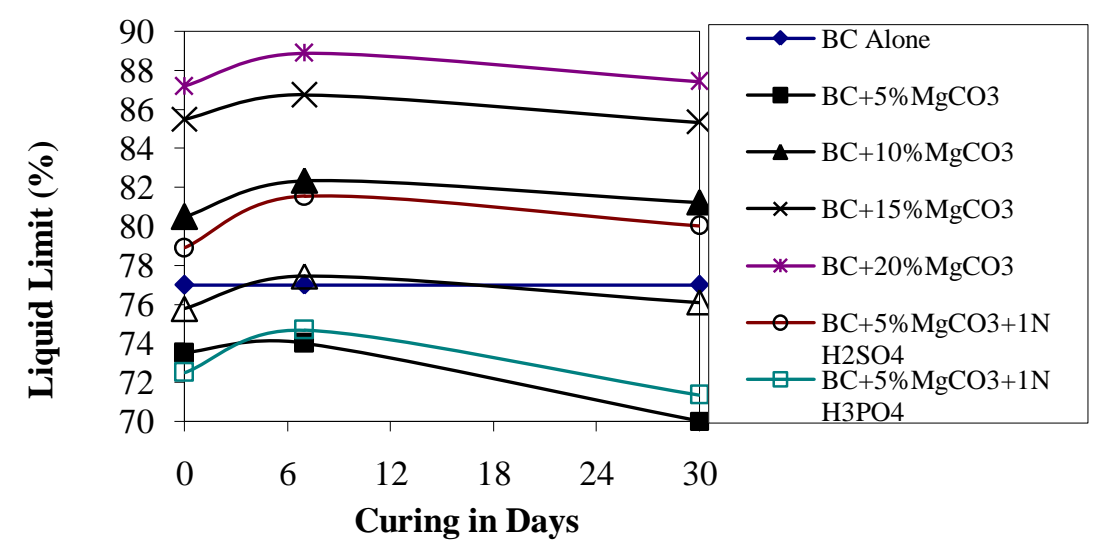

Fig 2. Variation of Liquid Limit of Black cotton soil with different percentage of additives at different curing periods.

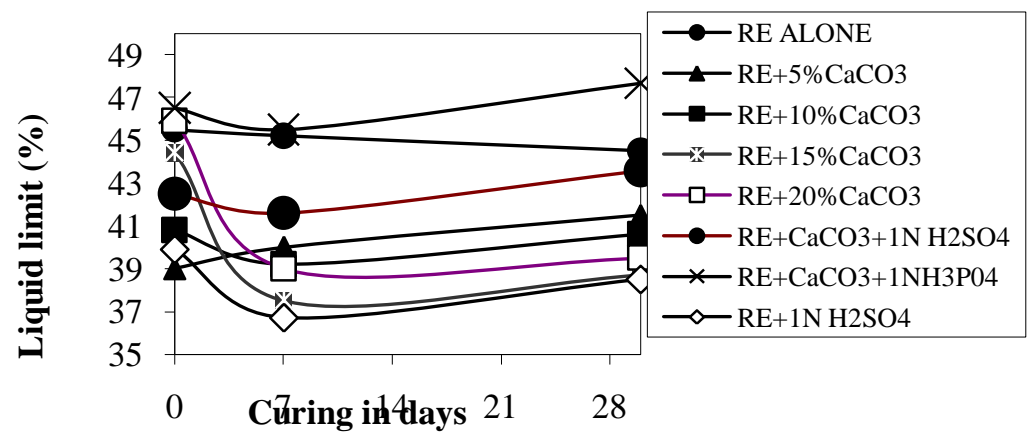

Fig 3. Variation of Liquid Limit of Red Earth with different percentage of additives at different curing periods.

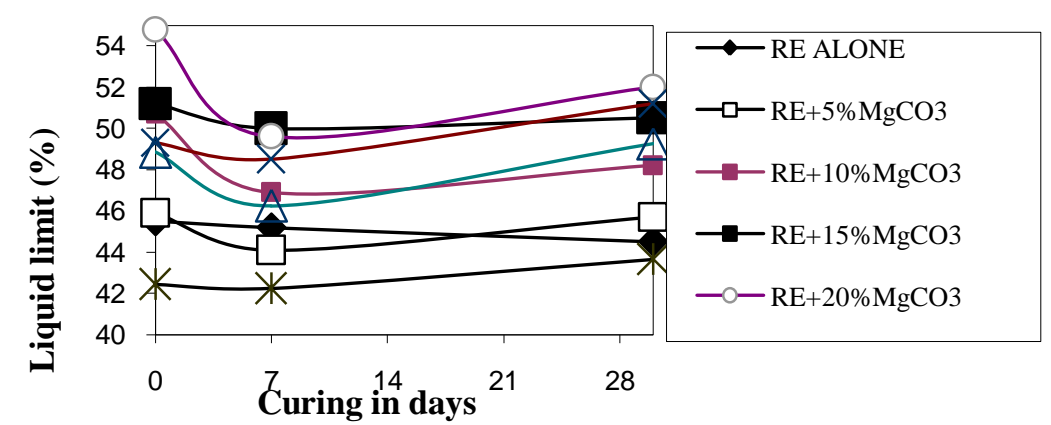

Fig 4. Variation of Liquid Limit of Red Earth with different percentage of additives at different curing periods.

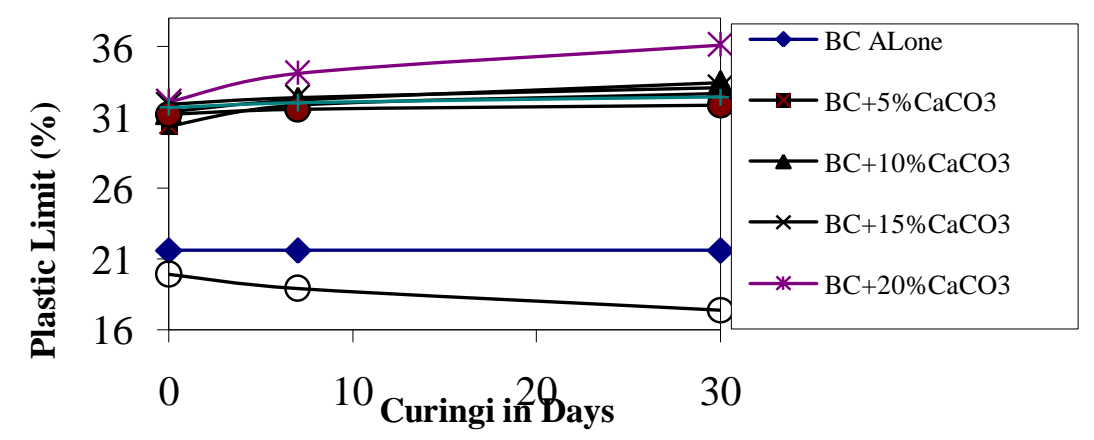

Fig 5. Variation of PlasticLimit of Black cotton soil with different percentage of additives at different curing periods. 


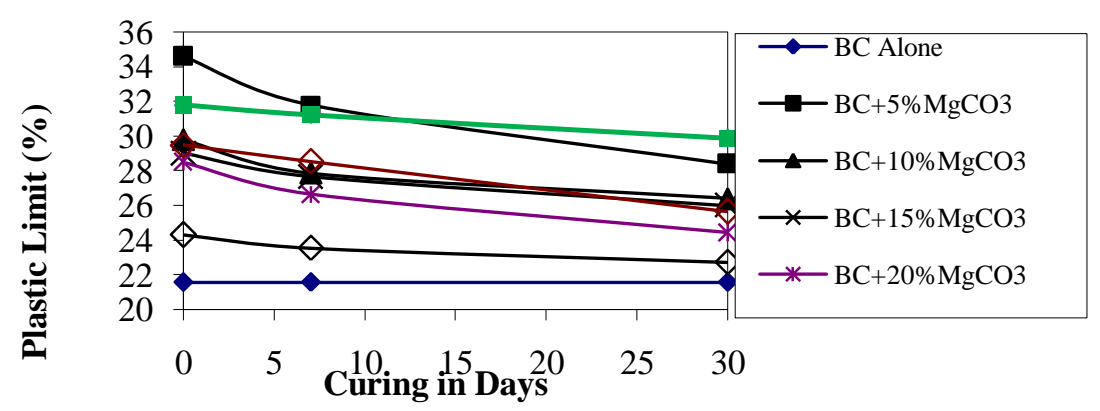

Fig 6. Variation of PlasticLimit of Black cotton soil with different percentage of additives at different curing periods.

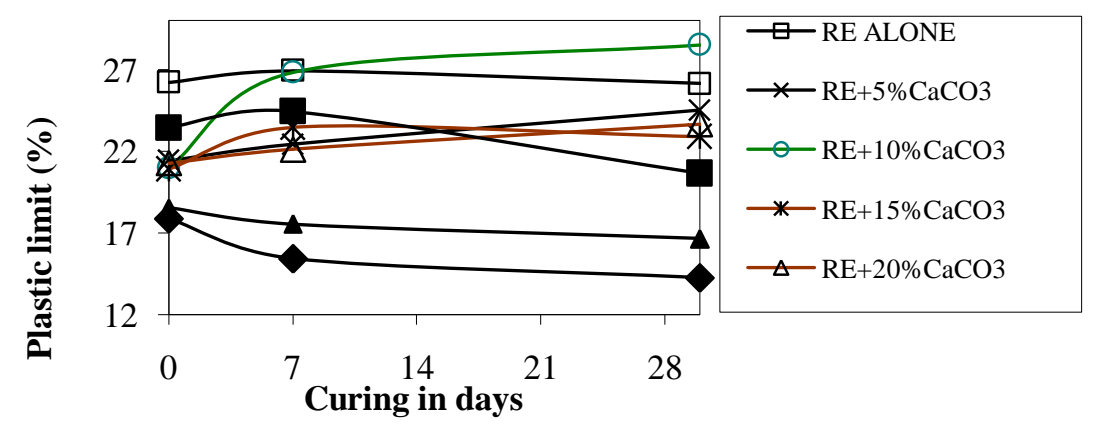

Fig 7. Variation of Plastic Limit of Red Earth with different percentage of additives at different curing periods.

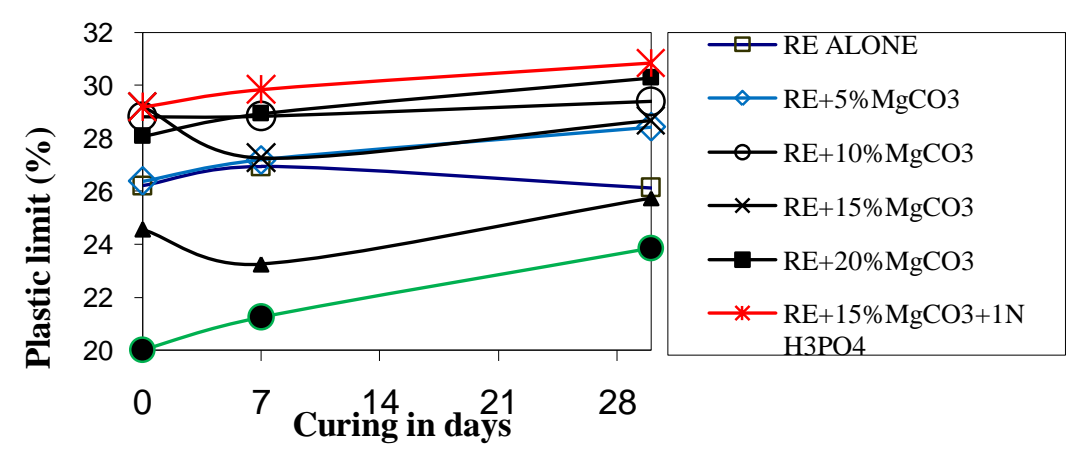

Fig 8. Variation of Plastic Limit of Red Earth with different percentage of additives at different curing periods.

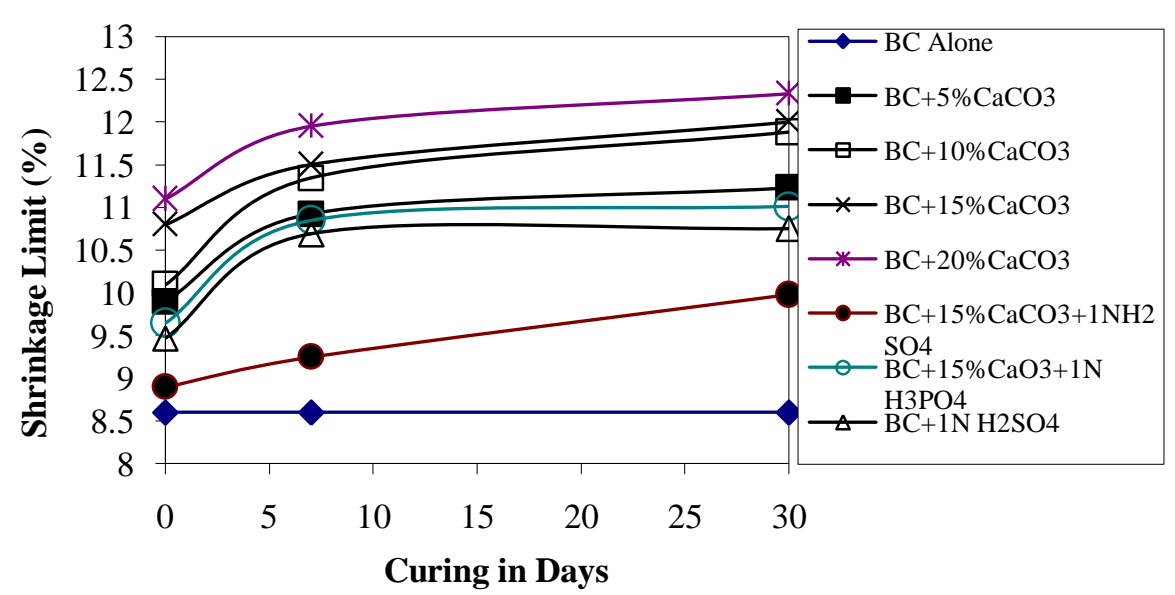

Fig 9. Variation of Shrinkage Limit of Black cotton soil with different percentage of additives at different curing periods. 


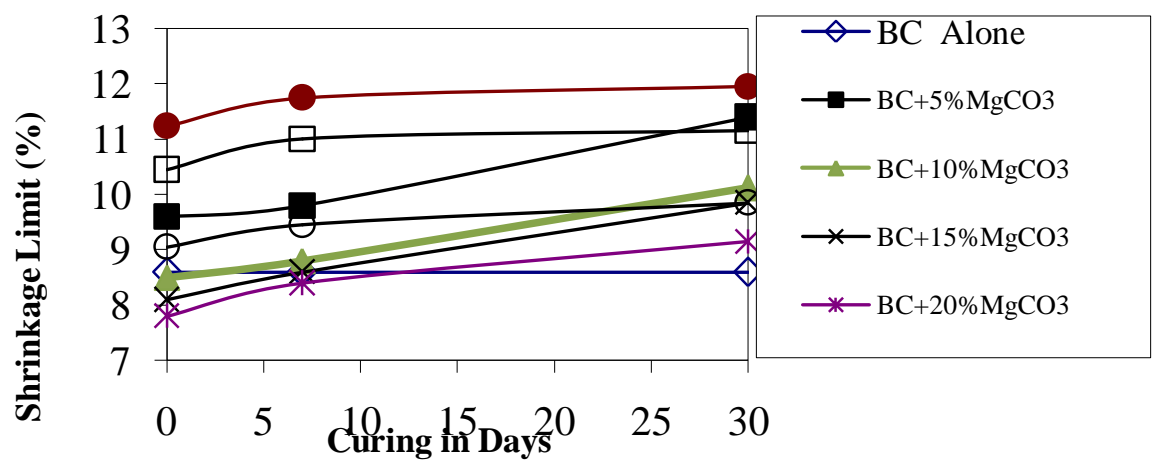

Fig 10. Variation of Shrinkage Limit of Black cotton soil with different percentage of additives at different curing periods.

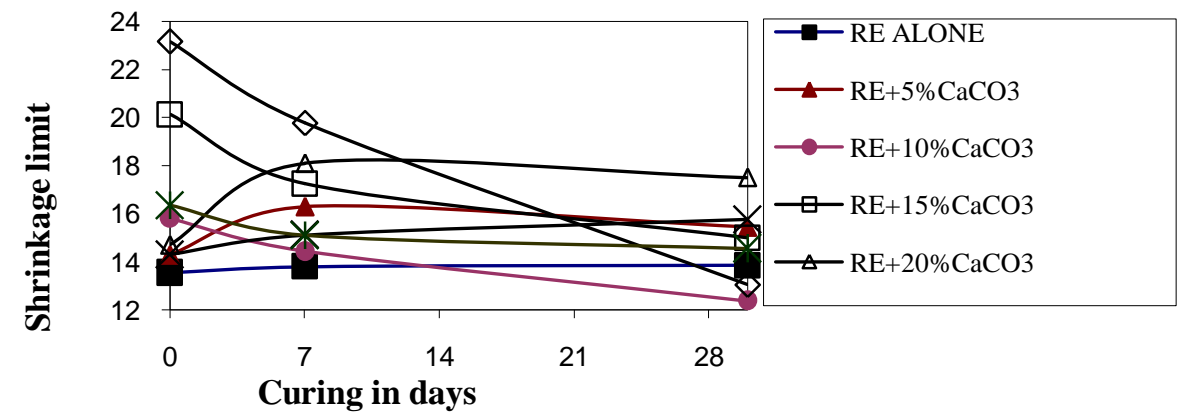

Fig 11. Variation of Shrinkage Limit of Red Earth with different percentage of additives at different curing periods.

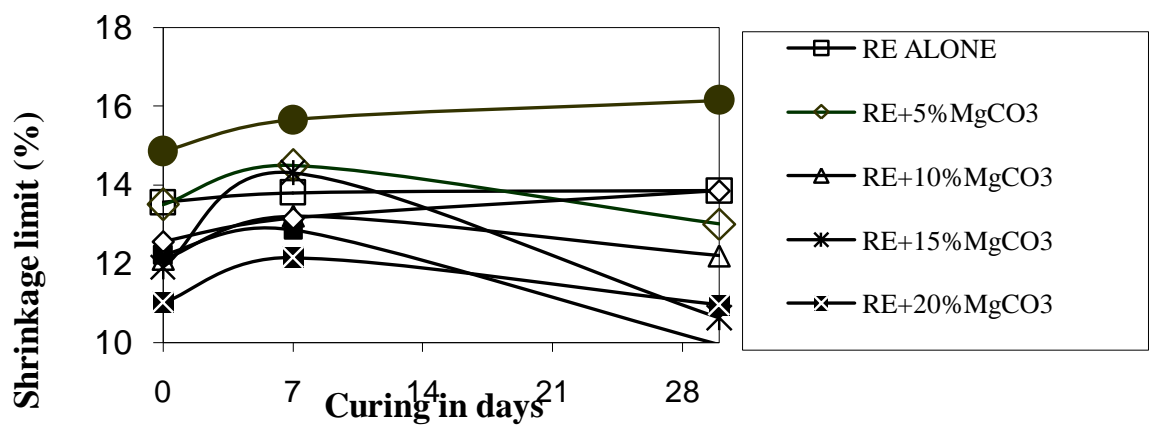

Fig 12. Variation of Shrinkage Limit of Red Earth with different percentage of additives at different curing periods.

\section{CONCLUSION}

1. The optimum percentage of $\mathrm{MgCO}_{3}$ and $\mathrm{CaCO}_{3}$ to Black Cotton soil was found to be $5 \%$ and $15 \%$ respectively.

2. Acidification of Black cotton soil treated with alkalis shown the negative effect of on the index properties. The effect of strong acid is more compare to the weak acid.

3. The optimum percentage for $\mathrm{CaCO}_{3}$ and $\mathrm{MgCO}_{3}$ additions to Red Earth is found to be $15 \%$ and $10 \%$ respectively based on compaction test.

4. The negative effect of Ortho Phosphoric acid is less on index properties compared to Sulphuric acid effect, however with $\mathrm{CaCO}_{3}$ and $\mathrm{MgCO}_{3}$ some of the index properties were improved upon curing for Black Cotton soil and Red Earth. 


\section{References}

[1]. Sridharan A, Nagaraj T.S and Shivapullaiah P.V, Heaving of Soil due to Acid Contamination, Proceedings of XI ICSMFE, Stockholm, 2, 1981, 383-386.

[2]. Joshi RS.C, Pan X and Lohita P., Volume Change in Calcareous Soils due to Phosphoric Acid Contamination, Pro. Of the XIII ICSMFE, New Delhi, 4. 1994, 1569-1574.

[3]. Kumpaley N.K and Ishola A., The effect of Chemical Contamination on Soil Strength, Proceedings of XI ICSMFE, Sanfransciso, .3, $1985,1199-1201$

[4]. Anand J Puppala, , Sulfate Heave Mechanisms in Chemical Treated Clay, Proceedings of Indian Geotechnical Conference-2006, 1, 2006, 95-104.

[5]. Isbell, R.F. 1996, “The Australian Soil classification”, CSIRO, Collingwood, Victoria

[6]. Sivapullaiah, P.V., and Manju, Kaolinite-Alkali interaction and Effects on Basic Properties, Geotechnical and Geological Engineering, 23, 5, 2005, 601-614

[7]. IS 1498:1970, First Revision, Classification of Soils for General Engineering Purposes, ISI, New Delhi.

[8]. IS 2720:1985, Indian Standard Methods of test for soils, Part 5, Determination of liquid limit and plastic limit.

[9]. IS 2720:1972, Indian Standard Methods of test for soils, Part 6, Determination of shrinkage factors.

[10]. A Text Book of Soil Chemical Analysis by P.R.Hesse, Published by Chemical Pub. Co., University of Michign, 1972.

[11]. Sridharan A and Sivapullaiah P. V, Mini compaction test apparatus for fine grained soils, Geotechnical testing Journal, 28(3),2005,1-20.

[12]. Sivapullaiah, P.V., and Sitharam, T.G., Geoenvironmental Engineering and Waste Management,- QIP Short term course lecture notes compiled, 1999, Centre for Continuing Education, Indian Institute of Science Bangalore, 1999.

[13]. A.M.O. Mohamed and H.E.Anita, Geoenvironmental Engineering. Elsevier, Amsterdam, 1998

[14]. http://www.astm.org 